\title{
EDUCATION OF STUDENTS WITH DISABILITIES BY USING ON- LINE INTERNET APPLICATIONS AT THE UNIVERSITIES IN THE CZECH REPUBLIC
}

\author{
Radek Kratochvíl ${ }^{1}$, Mária Jánešová ${ }^{2}$ \\ ${ }^{l}$ Czech Technical University, Faculty of Transportation Sciences, Department of Logistics and Transport \\ Management, Konviktská 20, Prague 1, Czech Republic \\ ${ }^{2}$ Czech Technical University, Faculty of Transportation Sciences, Department of Logistics and Transport \\ Management, Konviktská 20, Prague 1, Czech Republic
}

\begin{abstract}
This article describes education of persons with disabilities through e-learning and other on-line communication / internet applications, especially for students with disabilities at the universities in the Czech Republic. Study environment should be adequately adapted to these students. An appropriate tool is to create an on-line communication web portal connecting e-learning as a form of long distance communication enabling the active participation of the student in lectures and e-consultation providing a support for subsequent individual one-on-one consultations. These e-consultations can be paid and may be provided by teachers or advanced students. By implementing this online communication application, effective distance learning and expert advice will be provided to working age students that have limited time and a tight schedule as well as to students with disabilities who generally have problems with relocation. The e-learning and e-consultations should be sufficient for a large number of scientific and academic disciplines. Appropriate online communication tools are applications that allow bilateral audio-video streaming, chatting, sharing of documents or performing tests. The interest in this type of study and this kind of individual consultation using a simple web form has been successfully verified in the practical part of the thesis and implemented during doctoral studies at Faculty of Transportation Sciences of Czech Technical University in Prague.
\end{abstract}

Keywords: E-learning, persons with disabilities, research

\section{INTRODUCTION}

The aim of this paper is to describe the on-line teaching and tutoring students at the universities in Czech Republic. To provide this training and subsequent supplementary tutoring (considered paid), has been selected target group of teachers - people with disabilities. These persons should be able to make this work from home (for some of these people it is the only possible solution taking into their disability). The interest and qualification of these persons for this work is illustrated conducted surveys and statistics. E-learning method of teaching and tutoring by experts, from among persons with disabilities is substantiated by operating of the unique web portal created in the context of dissertation study at the Technical University.

\section{STATUS OF PERSONS WITH DISABILITIES}

In the Czech Republic lives according to statistics from 2010 , about $7 \%$ of persons with disabilities of the total population. Many of these people have such a disability that allows you to work on a PC. To confirm this and many other facts we use researched upon order the Ministry of Labour and Social Affairs of the Czech Republic. This survey (analysis) called „The position and strategy of persons with disabilities on the labor market“ (original name „Postavení a strategie OZP na trhu práce“) worked in 2011 by VÚPSV, v.v.i. The research was subsidized by the European Social Fund and is available in full on the website:

http://portal.mpsv.cz/sz/obcane/zamestnavani_ozp/helpforth em/hlavni_vystupy_projektu_a_jejich_prinosy/dotaznikove_ setreni_ozp_na_trhu_prace.pdf (pouze v českém jazyce).

Data collection in this survey was conducted through personal interviews in households in the term June - August, 2011. Attended by in total 2,084 persons with disabilities between the ages 18-65 years. The selection of respondents was conducted using quota sampling. Individual quotas were set on age, gender, type of disability, degree of disability, education, and region. Due to the need to make some more detailed analysis, quotas were adjusted for the benefit of under-represented groups persons with disabilities (eg, were interviewed more younger people).

Persons with disabilities (pictured) represent approximately $7 \%$ of population of working age, which corresponds to almost 500,000 individuals (LFS 2010).

Picture 1: Persons with disabilities in the Czech population. Source: http://portal.mpsv.cz 


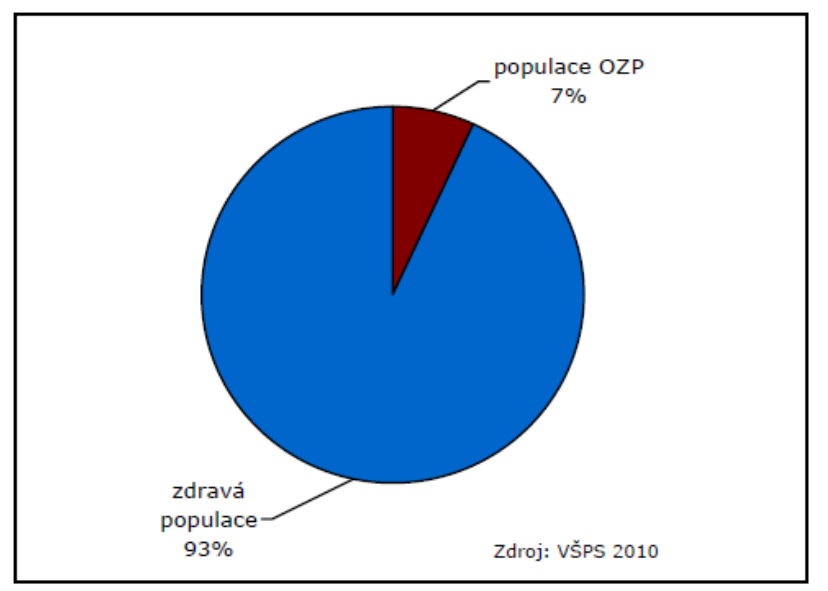

The following table gives us information on the type of disability depending to education of persons with disabilities. We determine the appropriate group of people for the purposes of the university on-line learning (from the table). These are people with a university education who have physical, visual and internal disability.

Table 1: Education on the basis of main type of disability. Source: http://portal.mpsv.cz

\begin{tabular}{|l|l|l|l|l|l|l|}
\hline $\begin{array}{l}\text { The proportion of the } \\
\text { population persons with } \\
\text { disabilities }\end{array}$ & Education & Physical & Visual & Hearing & Mental & Inner \\
\hline $5,40 \%$ & basic (incomplete) & $1,7 \%$ & $4,3 \%$ & $2,0 \%$ & $37,6 \%$ & $1,2 \%$ \\
\hline $19,60 \%$ & basic (complete) & $18,1 \%$ & $28,2 \%$ & $10,2 \%$ & $59,3 \%$ & $14,3 \%$ \\
\hline $68,30 \%$ & secondary & $75,2 \%$ & $48,7 \%$ & $83,3 \%$ & $89,7 \%$ & $76,2 \%$ \\
\hline $5,40 \%$ & higher and academic & $5,1 \%$ & $6,0 \%$ & $3,7 \%$ & $3,7 \%$ & $8,4 \%$ \\
\hline $1,30 \%$ & never attended & $0,0 \%$ & $2,9 \%$ & $0,8 \%$ & $9,8 \%$ & $0,0 \%$ \\
\hline $100,00 \%$ & & $100,0 \%$ & $100,0 \%$ & $100,0 \%$ & $100,0 \%$ & $100,0 \%$ \\
\hline
\end{tabular}

In this survey was found that $70 \%$ of the unemployed persons with disabilities are interested in working from home and $19 \%$ of employed people are interested in working with a PC.

Table 2: Work from home and interest in it. Source: http://portal.mpsv.cz

\begin{tabular}{|l|l|l|}
\hline Work from home & Employed & $\begin{array}{l}\text { Unemployed } \\
\text { interested in working } \\
\text { from home }\end{array}$ \\
\hline Yes - positive interest & $17,0 \%$ & $70,0 \%$ \\
\hline No - negative interest & $83,0 \%$ & $26,0 \%$ \\
\hline Not know & $0,0 \%$ & $4,0 \%$ \\
\hline Number of persons & 479 & 167 \\
\hline
\end{tabular}

Table 3: Working by phone or PC. Source: http://portal.mpsv.cz

\begin{tabular}{|l|l|}
\hline work over the phone or on the computer & Employed \\
\hline Yes - positive interest & $19,0 \%$ \\
\hline No - negative interest & $81,0 \%$ \\
\hline Number of persons & 479 \\
\hline
\end{tabular}

In this survey was found that the target group persons with disabilities has a very reasonable monthly salary requirements. This salary corresponds (it is rather below average) to the monthly salary of university teachers.

Table 4: The idea of a reasonable salary. Source: http://portal.mpsv.cz

\begin{tabular}{|l|l|l|l|l|l|}
\hline $\begin{array}{l}\text { The proportion of } \\
\text { the population }\end{array}$ & $\begin{array}{l}\text { folary } \\
\text { acceptance job }\end{array}$ & Employed & $\begin{array}{l}\text { Looking } \\
\text { job }\end{array}$ & $\begin{array}{c}\text { for } \\
\text { Eot looking } \\
\text { previously sought }\end{array}$ & $\begin{array}{l}\text { Not } \\
\text { looking } \\
\text { never sought }\end{array}$ \\
\hline $10,90 \%$ & less - 4.999 CZK & $11,90 \%$ & $6,30 \%$ & $15,10 \%$ & $16,90 \%$ \\
\hline $24,20 \%$ & $5000-9999 \mathrm{CZK}$ & $38,60 \%$ & $33,20 \%$ & $32,00 \%$ & $26,50 \%$ \\
\hline $25,60 \%$ & $10000-14999 \mathrm{CZK}$ & $27,30 \%$ & $43,70 \%$ & $29,50 \%$ & $36,60 \%$ \\
\hline $10,20 \%$ & $15000-19999 \mathrm{CZK}$ & $15,10 \%$ & $11,40 \%$ & $14,70 \%$ & $11,80 \%$ \\
\hline $5,90 \%$ & $20000-$ more CZK & $7,00 \%$ & $5,30 \%$ & $8,80 \%$ & $8,20 \%$ \\
\hline $23,10 \%$ & not filled & & & & $100,00 \%$ \\
\hline $100,00 \%$ & & $100,00 \%$ & $100,00 \%$ & $100,00 \%$ & \\
\hline
\end{tabular}

3. ON-LINE COMMUNICATION WEB PORTAL Confirmation of the fact that these persons with disabilities are willing and competent to carry out on-line learning (e- 
learning) and on-line individual consultations for students (e-consultation) has been verified by developing and operating a web portal. I created this web portal as part of my dissertation. The portal allows you to provide and use on-line learning and consultation.

These services are provided by experts selected from among persons with disabilities. These people do this work from home by using PC. Joined the project in total 30 people with disabilities with a university education. These people provide on-line learning and consultation in scientific fields such as mathematics, physics, social work, teaching of foreign languages and more.

\section{CONCLUSION}

Finally I would like to noted that this work is from persons of disabilities in great demand. The interest is so great that we cannot satisfy all those interested in this job. By implementing a web project has been verified interested in this service by students and overall great benefit of this service. We are currently collect all the data, which will be subsequently be evaluated and incorporated into the dissertation.

\section{REFERENCES}

[1] Haythornthwaite, C.: E-learning theory and practice / Caroline Haythornthwaite and Richard Andrews. London, Sage Publications, 2011, ISBN 978-184920-471-2

[2] Duchoň, B.: Inženýrská ekonomika. Praha, C.H.Beck, 2007, ISBN 978-80-7179-763-0

[3] MINISTERSTVO PRÁCE A SOCIÁLNÍCH VĚCÍ. Portal.mpsv.cz [online]. [cit. 2014-03-10]. Dostupné z: http://portal.mpsv.cz

[4] MINISTERSTVO PRÁCE A SOCIÁLNÍCH VĚCÍ. Mpsv.cz [online]. [cit. 2014-03-10]. Dostupné z: http://www.mpsv.cz

[5] ČESKÝ STATISTICKÝ ÚŘAD. Statistiky. Czso.cz [online]. C2012 [cit. 2012-02-02]. Dostupné z: http://www.czso.cz/csu/redakce.nsf/i/statistiky

[6] KRATOCHVÍL, Radek. Úvod. Videokonzultace.cz [online]. [cit. 2013-10-01]. Dostupné z: http://www.videokonzultace.cz/s1-uvod.html

[7] Kratochvíl, R., Douda, V., Jánešová, M. \& Vopava, J.: E-Consultation - online Video Consultation with Experts. In S. Barton et al. (Eds.), Proceedings of Global Learn Asia Pacific 2011 (pp. 2217-2221), AACE, ISBN 1-880094-85-1

[8] Zelinka, T., Svítek, M.: Telekomunikační řešení pro informační systémy sít’ových odvětví, Grada, 2009, 218 stran, ISBN 978-80-247-3232-9

[9] Fábera, V., Jáneš, V., Jánešová, M.: The Distance between FSMs and its Computing Using Genetic Algorithm, Proceedings of CSE 2010 International Scientific Conference on Computer Science and Engineering. Košice: Technická Univerzita, 2010, p. 295-301. ISBN 978-80-8086-164-3

[10] Votruba, Z., Novák, M., Brandejský, T., Fábera, V., Bouchner, P., et al.: Theory of System Alliances in
Transportation Science, Praha: Ústav Informatiky AV ČR, 2009. 162 p. ISBN 978-80-87136-08-9 